\title{
Internet, Political Socialization, and Youth's Political Culture in the South of Brazil
}

\author{
Marcello Baquero \\ Political Science, The Federal University of Rio Grande do Sul, Porto Alegre, Brazil \\ Email: nupesal@yahoo.com.br
}

How to cite this paper: Baquero, $M$. (2017) Internet, Political Socialization, and Youth's Political Culture in the South of Brazil. Open Access Library Journal, 4: e4062.

https://doi.org/10.4236/oalib.1104062

Received: October 23, 2017

Accepted: November 19, 2017

Published: November 22, 2017

Copyright (C 2017 by author and Open Access Library Inc.

This work is licensed under the Creative

Commons Attribution International

License (CC BY 4.0).

http://creativecommons.org/licenses/by/4.0/

(c) (i) Open Access

\begin{abstract}
From a conventional theoretical perspective on political science, technological media is considered a powerful inductor of young citizen's attitudes and behavior. The Internet is generating an environment where new forms of social interaction between politics and society take place. These tools were widely used by Brazilian youth in protests against the government in July 2013. Could this be the beginning of a new process of political socialization? I believe that this new media technology is structuring new collective identities and some forms of political sophistication among the youth. I hypothesize that this type of political involvement, taking into account the type of youth's political culture, does not contribute for the construction of a new sense of citizenship among the young citizens. The main objective of this paper is to evaluate the effect of the use of Internet in the political socialization process of the youth (13 to 24 years old) in the South of Brazil. The data utilized is the result of a survey research conducted from March 2015 to April 2016 with 1964 adolescents in public and private high schools selected through multistage probabilistic sampling. The questionnaire consisted of $70 \%$ of structured questions and $30 \%$ of open questions. The results showed among the young citizens a conformism which results from a feeling of impotence, of not being capable of doing something to change things, and hostility with the political institutions that do not provide equal opportunities for participation for the youth. Furthermore, it is argued that the use of Internet has not had a significant impact in the construction of another type of youth's political culture.
\end{abstract}

\section{Subject Areas}

Politics

\section{Keywords}

Youth, Internet, Political Socialization, Political Culture 


\section{Introduction}

Despite the significant number of young citizens in Brazil, analysis about the production of knowledge regarding this group indicates that we are far from understanding how they construct their political imaginary in a postmodern world. Most of studies YOUNG [1], NAZZARI [2], MUXEL [3], BAQUERO and CUNHA [4] related to the youth in Brazil, focus mainly on political participation, their practices, values and representations, based upon theoretical models observed in the 1960's and 1970's. These studies of a historical nature analyzed the student's mobilizations during the military regime. Other studies have emphasized another type of youth's political participation related to a new political context of citizenship affirmation especially during the 1990's. Those studies seek to uncover the motives underlying the youth's involvement or not in social and political questions focusing on aspects related to the political socialization process and the development of citizenship.

Analyzing the research about "youth and emerging themes" (in which youth and politics are included), it has become imperative to re-dimension the focus of the investigations, in order to produce a wider perspective in examining this issue. Citizen participation has always been a concern in political science. Since the classics, the goal has been to understand the role of human behavior in the political dimension. However, studies that examine this question from the political culture perspective have not prospered in Brazil. Research going beyond the institutional approach would enhance our comprehension of how the contemporary youth decodes politics and how they internalize political values and beliefs. Although efforts in this direction have been made, there are still wide gaps, especially regarding important issues such as: their role in the democratic construction/consolidation of a society, the influence of political personality development in the constitution of a youth political culture and, how new media technologies are influencing the political personality through the process of political socialization.

From this perspective, what is new in the area of political socialization in contemporary Brazil refers to the role of the Internet in the structuring of political values, beliefs and political personality. In this context, the research question that we seek to answer in this paper is: what is the influence of the Internet as a mechanism of political socialization in the process of youth's collective identity formation in the political culture in the south of Brazil?

The article seeks first to contribute recovering a tradition of political socialization studies in Brazil. Second to present valuable survey data about how the youth are internalizing political values (positive or negative) in a particular point of time (political turmoil), and third to analyze how the Internet and social networks are creating or not a new mechanism of political culture construction. The main objective of this paper is, therefore, to make a valuable contribution to the field of political culture construction identifying new patterns of political socialization through Internet and social networks. 
The article is divided as follows. In the first part, aspects related to the historicalstructural factors that influence the formation of youth's political personality in Brazil are discussed. In the second part, the Brazilian political culture development is analyzed. In the third part, utilizing data from a probabilistic survey with 1964 young citizens between 13 and 24 years old in three cities of the South of Brazil (Porto Alegre, Curitiba and Florianopolis), the role of Internet as a mechanism of political socialization is evaluated. Finally, we present some tentative conclusions.

\section{Political Culture in Brazil: Historical Characteristics}

Citizens' beliefs and political values as well as their ideas about their political system, their level of information regarding norms and procedures, institutions and authority structures constitute significant elements of political opinion formation. In this context, the processes through which citizens internalize their political orientations are central in their public opinion formation Sartori [5]. Opinions derive from a multiplicity of factors, especially those related to political communication. From a historical point of view, public opinion formation goes back to two sources: 1) in primary society and 2) in mass society. In the former, public opinion emerges from citizen's level of associating in a community in order to achieve some consensus regarding public questions Young [6]. The latter form of public opinion formation, results from the Industrial Revolution, which altered significantly how citizens began to acquire new attitudes and values. New media technologies, urban life, new types of political and economic relations and a process of complexification of day-to-day problems (going from the local to the global) substituted personal interrelations and face-to-face interactions. At this historical junction, citizens began to experiment availability of huge amounts of information through indirect sources of information and interpretation, that is-new mass media.

One of the significant changes in the democratization period in Brazil refers to the influence of new media technologies in the role of the youth in politics. More specifically, it has been observed that the youth manifest contradictory attitudes and behaviors in relation to politics. On the one side, they demand more participation spaces and, on the other side, are increasingly cynic of political democratic representative institutions. This paradox is a consequence of the democratic construction process in this country, in which the institutionalization of electoral democracy occurs, simultaneously, with a growing distancing of the youth from the political conventional arena. Under these circumstances, the probability of emerging a political culture in which citizens, especially the youth, questions the present design of democracy increases.

Several factors could be responsible for this situation. Some of these factors include economic, political and social structural changes, as well as, technological changes and changing working conditions. Furthermore, as previously observed, the appearance of media technologies-television and Internet-has 
created an environment for the emergence of social networks and virtual communities. In this perspective, in order to evaluate the democratic progress in Brazil, based upon the role of the youth's political formation, recent studies have included in their analysis variables and concepts that traditionally were excluded from the democratic equation (political culture, social capital, political socialization and the role of the media) Klicksberg [7].

Traditionally, the youth as a category of analysis was associated to some type of crisis (unemployment, non-conventional participation, early parenthood, drug problems and sexual transmitted diseases). This perception has not changed significantly. At the same time, it is expected that the youth play a central role in the modernization process. However, in the case of Brazil studies that examine the type of political personality the youth develop related to political subcultures and citizens' democratic construction process are scarce. The youth is seen, simultaneously, as a problem or as a solution and not as members of a global community or society, whom face problems in their day-to-day activities Touraine [8].

What does it mean to be young presently? From a conceptual point of view youth is a social age and not a development period to become an adult Bourdieu [9]. The United Nations establishes the age between 15 and 24 years as being young. 3) During this period emotional instability and the changes mentioned above contribute for the increasing of the vulnerability of the youth to a series of risks.

In the case of Brazil, Baquero [10] shows that the youth suffers from an unequal distribution of resources as well as an unequal access to public resources. In this context the youth is a vulnerable category, because not only they are young, or they are in a phase in which they experience rapid transitions, but because all type of institutions is not accessible for them. Although significant advances materialized in Brazilian democracy in terms of some reforms in the areas of civil, economic, political and social rights, the same is not true when the issue refers to problems of social inequality and concentration of wealth and its impact on the youth. These problems affect attitudes and behaviors formation of the young citizens that question the legitimacy of democratic institutions and the results of public policies in strategic areas, such as citizen's safety, health, education, housing and equality of opportunities.

Under these circumstances of asymmetries between the formal and the real day-to-day of the youth, it comes as no surprise to observe that in relation to democracy, in a diffuse sense, they manifest a solid support. However, at the same time there is an increase in protests, increase in political distrust, and the search for other forms of political engagement beyond the conventional forms of participation. In this context, new information technologies (especially the Internet) have made possible the formation of social networks utilized to show dissatisfaction with the political and economic situation of the country. How these new forms of collective identities formation will affect modes of presenting 
demands from the youth to the State, at this point, is uncertain.

From an embrionary point of view, the effect of these new media technology in youth's political engagement seems positive, and could strengthen political institutions, demanding more accountability and better results in terms of public policies. Additionally, these media, in the last years, has become for the youth a complement, and in some cases a substitute of formal conventional modes of political participation.

As a result, studies about the effects of the media in public opinion is accelerating in Brazil as electoral public opinion surveys show CESOP [11], FUNDAÇAÕ TELEFÓNICA AO VIVO [12], MIGUEL [13], MESQUITA [14]. The political relevance of the media derives from the mediation of public discourse and reality. However, in order to understand the impact of the Internet on political attitudes and behavior of the youth, it is necessary to examine how the historical development of political culture occurred.

\section{Political Culture}

The Brazilian State, contrary to the European nations, was never capable of expressing its own history, becoming a receptive importer of the western hemisphere values. One explanation is that in Brazil the State developed before civil society, contrary to western democracies where society structured before the State, guarantying the strengthening of citizenship and turning the State accountable to the people. The consequence of the overdose of "State sovereignty" in Brazil was the institutionalization of a hybrid political culture that, on the one hand, internalized western values and, on the other hand, lives in a precarious social and economic reality. In fact, in order to understand the historical specificities of Brazil a review of the meaning of politics and the nature of existing social relations is necessary. A retrospective analysis of Brazilian history shows the influence of a political and economic instability, as well as an authoritarian lega$c y$, on the obstruction of the development of a civic political culture.

An important Brazilian historical author Oliveira Viana [15], writing in a cultural perspective, argue that, from the point of view of the structural matrix of Brazilian sociability, the clientelism and personalism dimensions as well as the supposed incapacity of Brazilian citizens in mobilizing autonomously, compromised the exercise of accountability and potential modifications in the political process.

The historical dynamic of Brazil State's evolution, according to those authors, established the bases upon which values of disaffection; withdrawal and political apathy did not contribute for an effective political efficacy. This tendency, therefore, privileged the non-participation and political inertia. In this context, the predominant perception of the Brazilian State was of being incapable of introducing structural reforms that could generate a civic culture, producing a deficient mediation between State and society.

Such setting was not substantially altered with the institutionalization of the 
technocratic State in the 1950's, which continued to foment citizens' withdrawal from the political arena, promoting, at the same time, an insignificant role of Congress in the decision making process, and institutionalizing what was called as the executive hypertrophy. Such situation, according to Oliveira Viana [15], a respected historian of Brazilian politics, could only be solved by the institutionalization of an authoritarian centralized system, capable of generating a truly national State. In synthesis, the technocratic state of this period did not eliminate clientelistic, personalistic and corporatist practices leading to the institutionalization of what were known as a patrimonialistic State Uricoechea [16].

One of the more influential historians of Brazil Buarque de Holanda [17], argued that Brazilian political history paved the way for the establishment of four elements that affected the type of political culture constituted and the values and beliefs of citizens about politics. These factors were first, the absence of a tendency for self-government. Second, the absence of community oriented solidarity and a spontaneous form of political self-organization, producing a value orientation that favors a lack of activism with people seeking external reasons for the existence of unacceptable realities, rather than trying to change them. Third, the reflective reasoning characterized by a political thought that impedes ruptures, generating a conservative consciousness and fourth political interests dominated by passions, instead of rational calculations of means-end relations.

In the 1980's, the cultural approach gained impulse with the study of Roberto DaMata [18] in which he concluded that citizenship in Brazil is constructed based upon personalist dimensions, vertical identity and the positive law. For the author, Brazilian society is hybrid because it combines a horizontal identity, typically western, based on natural law with a vertical identity, characteristic of non-western societies in which prevails tradition and cultural continuity.

Thus Brazilian political experience has been dominated by the predominance of authoritarian forms of government which produced constraints for a more effective political participation. The impact of authoritarianism did not create the bases where civil society could have a significant role. In the 1990's, despite the political mobilizations that contributed for the impeachment of President Collor de Mello in 1992, civil society continued to evidence a tendency for apathy and political distrust. This situation remains unchanged at the turn of the $21^{\text {st }}$ century.

In this context, Moises [19] has argued that, due to the hybrid political culture existing in Brazil, an important segment of people denominated as "ambivalent electors" have emerged, that is, those who support democracy in a diffused sense, considering it the best form of government, while at the same time they showed distrust and cynicism regarding political institutions. The result being weak political institutions and with reduced credibility. When formal representative procedures institutionalized, which are central in a democracy, without, however, offering a sense of political efficacy of inclusive citizenship and of widening the options for participation, electoral democracy does not produce a 
civic political culture.

When citizens, in a political system, do not feel protected by the public policies social malaise emerges. The consequence is the tendency for the development of negative predispositions towards politics, aggravated by a sense of uncertainty and insecurity regarding the future. When this feeling naturalizes in the population, it generates cynicism, hostility and political resignation. At the same time, interpersonal and institutional distrust institutionalizes and therefore, negative political values prevail which privilege personalism and backward forms of political mediation. Corruption also becomes rooted in the social and political relations generating a redesign of political values which, in the long run, causes political disempowerment of the citizens, in this case, the youth.

Such circumstances have produced feelings of being unprotected and abandonment among the Brazilian youth. They do not see in the State's actions, initiatives capable of improving their social and economic situation. Thus, the young citizens tend to produce their own version of citizenship, which is generally opposed to the State's conception, developing their own version of political culture.

\section{Youth's Political Culture, Norms and Values: Participatory Dimension}

Questioning youth's political participation, leads us to ask about the future of democracy and the development of Brazilian society, because this youth will be responsible for defining continuities or changes in societies and their institutions NOVAES [20].

Studies about youth participation teach us, according to Gauthier [21], that they were not always leaders of changes, but constituted a group that were always sensitive to changes, either as the initial beneficiaries or the initial victims of them.

In a research about political socialization conducted by the Center for Research of Latin America (NUPESAL-UFRGS) in 2001, in Porto Alegre, Rio Grande do Sul, with a sample of 600 subjects aged 15 to 21, it was observed the existence of reduced political mobilization with regards to participation in both conventional (formal) and non-conventional (community oriented and nonpolitical) movements. The data indicated that $45 \%$ of youth were not motivated to participate in cooperative activities with other persons. In the conventional dimension of participation, the percentage of those youth that are disinterested in getting involved in politics amounts to $78 \%$, suggesting a situation of total demobilization to engage in political activities of any nature.

Rute Baquero [22], utilizing survey data about youth's political socialization in the same city, in 1999 and 2002, with samples of 520 and 600 subjects respectively, analyzed youth's political participation between 14 and 23 years old. The data revealed the preponderance of youth's participation in social, sports and cultural activities and, a reduced involvement both in conventional and nonconventional political activities. A similar pattern of reduced conventional and 
non-conventional participation was observed in studies in different Brazilian cities by Lucas [23], Cunha [24], Silveira [25], Araujo [26] and Von Randow [27]. Thus, in order to comprehend the reasons that constraint or demotivate youth participation in conventional or non-conventional political activities it is essential to evaluate how they decode politics.

In surveys conducted in 2002 in different cities of Brazil, open questions were included in the questionnaire with the objective of better understanding how the youth decoded the political world construction process. These studies LUCAS [23], in Caxias do Sul, Rio Grande do Sul; Baquero [28], in Porto Alegre, Rio Grande do Sul; and Nazzari [29], in Cascavel, Parana showed troubling results regarding the form how the youth construct their representations of political institutions. The youth interviewed in all studies demonstrated a negative perception of politics, in both its institutional dimension (parties) and the structural dimension (government). This data contrasts with the positive perception regarding democracy, crystallizing the dichotomy presented by Easton [30] about diffuse support (generic, emotional and generally positive) of democracy and specific support (particular and related to the evaluation and performance of political institutions) of political institutions. This latter dimension can give some insight about the degree of credibility and legitimacy of a political system based upon youth's trust in politics.

\section{The Trust Dimension}

The principles underlying the democratic political system presuppose that the governments are responsible for the welfare of citizens, for the fair and just administration of the law, for the transparency of their actions and for making it possible for all citizens to have access to the political process. Derived from these principles, the underlying idea is that political systems, which fail to abide by these principles, have a high probability of showing reduced levels of political legitimacy.

One of the elements that influences directly in fomenting citizen's distrust in the political institutions is their perception about the degree of corruption in politics. Corrupt practices systematically undermine democratic political principles, and as a result diminish people's faith in the political process. Thus, corruption is an important indicator of political performance, and it leads to reduced support for democratic institutions. In this sense, political trust or support for the political system is also a central concept of a democratic and healthy civic political culture. Political scientists generally assume that citizens disgruntled with politics demand radical changes in the system. Data related to the opinions of the youth regarding corruption in politics and about politicians broken promises was examined in research carried out in 2000 and 2002 Baquero [28], and also in a study by Lucas [23]. Both studies showed that about $69 \%$ (mean of both studies) of youth replied that all politicians are corrupt. Equally, 98\% (mean of both studies) of youth agreed with the evaluation that politicians do 
not deliver on their electoral campaign promises.

Nazzari [2] presented similar results in a study about political socialization of youth in Paraná State. Baquero [10], in research with adolescents in Rio Grande do Sul found a similar pattern. Nazzari [2] showed that the youth have vague knowledge of national problems and lack fundamental democratic values such as interpersonal trust and in institutions. Baquero [10] observed a tendency to cynicism and disbelief regarding democratic institutional political practices, despite their positive manifestation about democracy in an abstract sense. This process known as a semantic differential Easton [30] is what produces ambiguity about the political culture in Brazil, because, from an emotional point of view, citizens tend to support the principle of a democracy, while, at the same time, because of past experience, do not trust political institutions or politicians. This process creates an ambivalent political culture where the formal dimension solidifies at the same time that societal legitimacy diminishes.

Another set of studies of qualitative nature FARINA [31], SOARES, [32], KLEIN [33], undertaken through "case studies", identified the degree of influence of the school in the political culture of junior high school students. Soares [32] in 2002 and Lucas in [23] analyzed the influence of basic and university formation, as well as that of the family, religion and mass medias regarding the relationship of young women with politics. Klein in 2006 investigated the impact of an action of a teaching institution in the formation of individuals seeking to understand the democratic representations of democracy and democratic school of students at the junior level.

Such a democratic design was found in societies with a high level of economic and political development. In this perspective, democracy could not be transmuted to politically unstable countries and with a legacy of intolerance. To implement, therefore, a democratic method out of context would tend to produce, as in fact is verified in Brazil, a hybrid political culture and, would affect consequently the possibilities of strengthening democracy as well as the possibilities and the form of democratic functioning. In this sense, we agree with Chang [34] when he argues that the efficient performance of formal institutions in advanced countries is due to the existence and the support of informal institutions that are not always visible. For example, habits of valuing democratic procedures, that is, a participant political culture.

Schmidt [35], in research about youth and politics, refers that there are a series of traces that reappear in the research located in diverse geographical points in Brazil: preference for democracy in an abstract sense, reduced political efficacy, disbelief in politicians and institutions, sensitivity for changing ideas, but without defined ideological orientations, reduced effective political participation.

In the last years, a new line of research has appeared that emphasizes changes in youth's political personality. Putnam [36] in his analysis of American youth has argued that in the half past century we have witnessed, for better or for worse, a giant swing toward the individualist (or libertarian) pole in culture, so- 
ciety, and politics. At the same time, researchers have steadily piled up evidence of how important social context, social institutions, and social networks-in short the communities-remain for the well-being and youth's opportunities. This leads us to examine the role of the Internet and social networks in the political culture construction process in Brazil.

\section{The Role of Internet in the Construction of Political Culture in the South of Brazil}

In the last decades, studies of political socialization have not been in evidence, and one of the reasons is that there is not much "new" about this field. However, with the advent of new technological Medias, especially the Internet and social networks have contributed to enlarge the scope of analysis insofar as new agents of political socialization are concerned.

The penetration of the Internet in practically all routine activities of an individual produced profound social transformations, as well as promoted the emergence of new phenomena such as the experiencing of real virtuality CASTELLS [37]. In this context, information technology has become one of the more significant factors that are present in contemporary society. This evolution in technologies revolutionized society, culture, economy and politics, among others, which could modify the traditional relationships structures. This occurs because people tend to increasingly depend on the Internet for new information, to perfect their knowledge, getting to know new people and conducting activities that consumes more of their time through, for example, bank transfers and business activities.

From the point of view of mobilizational frames theories Snow and Benford [38], it is claimed that people are more likely to protest if the protest grievance is framed in a rights discourse. Similarly, in research conducted by Diani and McAdam [39] they verified that social networks have a positive effect in strengthening social ties that foments the desire of joining activities of protest. Underlying this statement is the premise that people are more likely to join a protest if their friends or family also express the desire to get involved. Finally, and most topically, in an expansion on the dynamics of information chains theory EASLEY and KLEINBERG [40], recent research has highlighted the role of social media (here meaning Facebook, Blogs and Twitter) in motivating and mobilizing protesters BHUIYAN [41], BODE and MAKARYCHEV [42], BENNETT and SEGERBERG [43]. Based on this principle, citizens will become involved in movements when they use social media sources for information, and those that were already engaged in protests most probably relied on social media as a central informational source.

Those studies have generated different types of research regarding the democratic possibilities of Internet GOMES [44], SILVA [45], of how the digital interactions are constituted as proxies of the level of political participation and engagement LÉVY [46], CASTELLS [37], MAIA [47], EGLER [48], PENTEADO, 
SANTOS and ARAUJO [49], EISENBERG [50], as well as collective identities formation MAIA and CASTRO [51], MITRA [52], Acklanda and O'Neila [53], LAMB e POSTER [54], SOON and KLUVER [55].

The role of this new social media in the Brazilian hybrid political culture, could alter the political attitudes and behavior of the young citizens. Given the context of a permanent transitional process, the youth face an identity crisis, in which old references such as the family, church and school give way to virtual relationships.

Initially, Internet provides an interaction space in which people share their problems, their opinions, and debate several issues. Given this context, it is necessary to comprehend that Internet constitutes a base that structures those new relationships in the network society CASTELLS [37], cyberspace and cyber culture LÉVY [46]. According to Castells [37], the technological revolution and capitalism restructuration introduced new forms of society-the network society. This type of society "is characterized by the globalization of decisive economic activities from a strategic point of view; by its network organization, by work flexibility and instability, and by the individualization of labor". Furthermore, the author emphasizes that modern society is a "culture of real virtuality constructed based on a system of an omnipresent media, interconnected and highly diversified, and by the transformation of material bases of life-time and space.

Does Internet help to produce a political youth more politized? In this article it is postulated that the increase of Internet contacts or joining social networks do not necessarily increase the youth's political sophistication nor is conducive for the constitution of a more assertive political culture.

Having equal access to the Internet does not mean that everyone gains equal benefit from that access. Growth in basic user statistics does not necessarily mean that everybody is taking advantage of this technology in similar ways. For example, in a qualitative study conducted by Putnam in the USA [36] he found that compared to their poorer counterparts, young people from upper-class background (and their parents) are more likely to use the Internet for jobs, education, political and social engagement, health, and newsgathering, and less for entertainment or recreation. In a world where information is easily available strong personal networks and access to helpful people often matter more than access to the information itself. Just because teens can get access to technology that can connect them to anyone anywhere, does not mean that they have equal knowledge and opportunity.

According to Putnam, although lower-class kids are coming to have virtually equal physical access to the Internet, they lack the digital savy to exploit that access in ways that enhance their opportunities. At least at this point in its evolution, the Internet seems more likely to widen the opportunity gap than to close it Putnam [36]. Could this also be the case of Brazil?

\section{The Data}

There is nothing new when in Brazil research finds that today young citizens are 
Table 1. Interest in politics (\%).

\begin{tabular}{ccc}
\hline & 2002 & 2015 \\
\hline Very interested & 25 & 22 \\
Little interested & 57 & 60 \\
Not interested & 18 & 18 \\
Total & 100 & 100 \\
\hline
\end{tabular}

n $2002=499 ;$ n $2015=1952$ (the number of cases refers to valid cases of a total of 1964 interviews in 2015). Source: Nupesal, 2002 e 2015.

not interested in politics. Their lack of interest fluctuates according to the political and economic conjuncture. Since 2005 to the present, corruption scandals, political and economic instability and a growing dissatisfaction with the functioning of political institutions are generating high levels of cynicism about democracy. As Table 1 indicates, taking as a parameter the level of interest in politics, the youth maintains a traditional pattern of passivity and cynicism regarding politics, which does not contribute to foster a civic political culture.

The data analyzed for two different periods of time with different samples (2002 and 2015), confirms the lack of youth's interest in politics. Seventy-eight percent of the respondents in 2015 (18 not interested and 60\% little interested), are in this category, compared with $75 \%$ in 2002.

These results are, from the perspective of what is expected of the youth in terms of political participation, negative. Regardless of technological advances, the availability of access to information through Internet and social networks, the level of interest of the youth about what is going on in the political arena maintains an unchanged tendency.

Some authors FREIRE [56], SOARES [32] have pointed out that Brazil lives, presently, a situation of hate dissemination through the social networks and intolerance in the Internet, producing dogmatic and, in some cases, fundamentalist political postures. In this case, we consider that those attitudes are consequence of the type of political culture existing in the country and we argue that the new communications media simply reinforce them. An important dimension that explains why the youth internalize negative postures towards politics can be found examining the feelings of abandonment of the youth by the State. When the young citizens were asked about how they felt regarding the economic, political and social situation, the majority responded negatively as can be observed in Table 2.

Despite the low interest demonstrated by the youth (Table 1), when compared with other dimensions (Table 2) the level of interest increases a little bit, however, it does not surpass the feelings of alienation, indifference and delusion which sums $60 \%$ of the respondents. The relatively high level of interest (30\%), I believe, is a diffuse sentiment that does not translate into effective participation which can also be explained by the sentiments of the young citizens regarding the country (Table 3 ). 
Table 2. How do you feel regarding politics? (\%).

\begin{tabular}{cc}
\hline Alienated & 18 \\
Indifferent & 25 \\
Deluded & 17 \\
Interested & 30 \\
Participative & 10 \\
Total & 100 \\
\hline
\end{tabular}

$\mathrm{n}=1964$. Source: Nupesal, 2015.

Table 3. What are your feelings regarding the country at this moment? (\%).

\begin{tabular}{cc}
\hline Insecure & 23 \\
Outraged & 42 \\
Frightened & 6 \\
Frustrated & 19 \\
Happy & 1 \\
Trusting & 1 \\
Satisfied & 1 \\
Safe & 1 \\
Other & 6 \\
Total & 100 \\
\hline
\end{tabular}

$\mathrm{n}=1964$. Source: Nupesal, 2015.

Outraged (42\%), insecure (23\%), frustrated (19\%) and frightened (6\%) are the feelings that predominate among the youth at this moment in Brazil, and these feelings, I argue, contribute for the lack of participation, increase in political distrust and the hate towards others identified in the Internet. Only $5 \%$ of the youth reported that they felt happy, trusting and satisfied with the country. Some answers in the other category were dissatisfied, deception, worried and ashamed.

Furthermore, the youth's opinion about politicians is negative. When asked to respond if they agreed that all politicians are corrupt $78 \%$ agreed. This high percentage signals the high level of distrust verified through the years regarding political representatives, aggravated by the news of corruption practices by public servants and politicians.

It is important, at this point, to evaluate if the Internet and social networks contribute to improve or to worsen the negative feelings regarding politics and society as well the distrust in political institutions. The results indicate that the Internet does not contribute to eliminate traditional values of apathy, distrust and little political engagement rooted in Brazil's political culture (Table 4).

In Table 4, Internet appears as an important agency of political opinion formation for the youth, substituting traditional agencies such as school and the church. The family continues to be the main socialization agency with $38 \%$. 
Table 4. To form an opinion about political issues, which of the listed institutions do you consider to be most important, and the second most important? (\%).

\begin{tabular}{ccc}
\hline & $\mathbf{1}^{\circ}$ & $2^{\circ}$ \\
\hline Family & 40 & 16 \\
Church & 3 & 6 \\
School & 18 & 16 \\
Friends & 3 & 12 \\
TV & 9 & 10 \\
Radio & 1 & 3 \\
Newspaper & 7 & 13 \\
Internet & 20 & 18 \\
Social networks & 2 & 6 \\
Total & 100 & 100 \\
\hline
\end{tabular}

$\mathrm{n}=1964$. Source: Nupesal, 2015.

Table 5. Do you trust in political information of the following sources (\%).

\begin{tabular}{cccccc}
\hline & TV & Radio & Newspaper/magazine & Internet & Social Networks \\
\hline Yes & 9 & 7 & 17 & 14 & 7 \\
More or less & 56 & 61 & 57 & 65 & 59 \\
No & 36 & 31 & 26 & 29 & 34 \\
Total & 100 & 100 & 100 & 100 & 100
\end{tabular}

$\mathrm{n}=$ 1964. Source: Nupesal, 2015.

What is noteworthy is that Internet is considered the second most important agency where the youth get their political information (18\%). The school that in the past was the second most important agency of political socialization is presently, as our data shows, tied with Internet. This seems to be a tendency; which future research could validate. Thus, it is necessary to analyze those data because as Recuero [57], Primo [58], Castells [37] and Rheingold [59] argue social networks are connections, interactions or virtual communities that emerge through Internet. When Internet is added to social networks, the percentage doubles (45\%). This result is suggestive of the growing influence of Internet in everyday youths' activities.

The same pattern appears when we analyze the association between trust and trust in the news from several sources. The data is in Table 5.

The data in Table 5 indicate that Internet (14\%) and newspaper and magazine (17\%) are the sources more trusted by the youth, although, when analyzed in overview all the media sources are not generally seen as trustful. It does suggest however, that there is a growing tendency of Internet becoming a more reliable source of information.

Beyond trust, $60 \%$ of the youth answered that social networks are instruments of political participation, while 33\% considered more or less, and 7\% disagreed. 
The paradox is that when asked if they participated of political protests organized through Internet $81 \%$ said no, and only $20 \%$ attended those protests. These answers show the difference between attitudes and behavior studied by Easton (1965). Despite the fact that the attitudes are pro protest, the level of involvement is far from the attitudes demonstrated. This confirms that the nature of youths' political culture in Brazil is of the subject type ALMOND and VERBA [60]. Participation in this sense is virtual, not contributing to foster a participant political culture.

Among the youth that participated in the June protests in 2013, the youth identified the Internet as being the main mechanism that influenced their decision to become involved in those movements (Table 6).

Even if we take into account the fact that some of our respondents were between 13 and 15 years old, the percentage of the total sample that participated of this protest is reduced (17.7\% of the total sample). The data in Table 6 indicate that $56 \%$ of the students that participated in the June protests were influenced by the Internet. However, when we crossed this information with political trust and interpersonal trust the image changes significantly.

First, we compared levels of political participation between 2002 and 2015 regarding some of the more important political institutions (Table 7).

Table 7 indicates that despite the influence of Internet according to the youth in their decision to get involved in political activities, retrospectively, there are no differences when compared longitudinally with 2002. The levels of participation remained unaltered. Even when there is not a requirement for the youth to physically get involved in political activities their virtual level of participation is low, as can be observed in Table 8.

Table 6. If you already have participated of protests, how much each of the following more influenced you (\%).

\begin{tabular}{ccccccccc}
\hline & Family & Church & Friends & Professors & TV & Radio & $\begin{array}{c}\text { Newspapers and } \\
\text { maganizes }\end{array}$ & Internet \\
\hline Very & 16 & 2 & 41 & 23 & 21 & 7 & 9 & 56 \\
More or less & 30 & 4 & 32 & 39 & 28 & 26 & 29 & 21 \\
A little & 22 & 5 & 12 & 18 & 16 & 23 & 21 & 9 \\
Nothing & 31 & 89 & 14 & 22 & 34 & 43 & 41 & 14 \\
Total & 100 & 100 & 100 & 100 & 100 & 100 & 100 & 100 \\
\hline
\end{tabular}

$\mathrm{n}=353$. Source: Nupesal, 2015.

Table 7. Institutional participation (2002 e 2015-2016) (\%).

\begin{tabular}{ccc}
\hline & 2002 & 2015 \\
\hline Political parties & 3 & 2 \\
Community associations & 3 & 5 \\
NGOs & 5 & 5 \\
\hline
\end{tabular}

n $2002=500$, n $2015=1964$. Sorce: Nupesal, 2002 e 2015-2016. 
Table 8. On Line political participation.

\begin{tabular}{ccccc}
\hline & Participates & Participated & Never participated & Total \\
\hline Signing petitions & 9 & 23 & 68 & 100 \\
Boycotts & 2 & 4 & 94 & 100 \\
Twitter & 3 & 12 & 85 & 100 \\
\hline
\end{tabular}

n = 1964. Source: Nupesal, 2015.

Table 9. Trust in the Internet and political participation.

\begin{tabular}{cccccc}
\hline & & Participates & Paticipated & Don't participate & Total \\
\hline & Political parties & 2 & 4 & 94 & 100 \\
& Community Associations & 4 & 13 & 83 & 100 \\
$\begin{array}{c}\text { Trust in the } \\
\text { Internet }\end{array}$ & NGOs & 7 & 9 & 85 & 100 \\
& Signing petitions & 9 & 37 & 52 & 100 \\
& Protests & 15 & 24 & 61 & 100 \\
& Social movements & 7 & 15 & 78 & 100 \\
\hline
\end{tabular}

n = 1964. Source: Nupesal, 2015.

Table 10. Institutional trust (2002 e 2015-2016) (\%).

\begin{tabular}{ccc}
\hline & 2002 & 2015 \\
\hline Political parties & 4 & 1 \\
Federal government & 5 & 5 \\
\hline
\end{tabular}

n $2002=500$, n $2015=1964$. Source: Nupesal, 2002 e 2015.

Although being a virtual participation, the levels of participation are not much different from physical participation. In order to try to understand what factor could explain this phenomenon, we crossed political participation levels with trust in the Internet (Table 9).

Regardless of the trust deposited in the Internet, the youth overall do not participate in the activities mentioned. Although, when we compared among the categories presented those who trust the Internet tend to participate in protests and participated more than in other political actions. This pattern of no participation was also observed in a survey research conducted in Porto Alegre in 2002.

In relation to institutional trust, Table 10 shows that from 2002 to 2015 there is a significant reduction from $4 \%$ to $1 \%$ of youth's trust in political parties while maintaining the same percentage (5\%) regarding trust in the federal government. I believe this situation is explained by the present circumstances in Brazil of political turmoil due to the corruption charges of several public elected officials. In this context, on the dark side, the use of Internet has contributed, in my opinion, for the proliferation of hostility feelings and intolerance from all political sides. 


\section{Conclusions}

In this article, I aimed to examine the role of Internet and social networks in the political culture construction process in the South of Brazil. Historical structural factors I argue have a decisive influence on the values and beliefs that the youth internalize and develop their political personality.

To be sure, the link between how the political culture is constituted and its effect on how the youth express their political attitudes and behavior is consistent. As the data from our survey research illustrates, political interest of the youth has not experienced significant changes in the last years. They continue to be passive, indifferent and hostile towards politics and politicians.

From the perspective of trust in political institutions, the picture is the same. Political parties and institutions associated with the government do not enjoy high levels of political support or trust from the youth.

In this context, is the Internet and social networks filling up this gap between state and citizens, specifically the youth? Our data indicate that the increase of political activities on the part of the young experienced little change as a function of the Internet and the use of social networks. The participation pattern of the past continues to the present, that is, noninvolvement in politics. Additionally, because of the political turmoil of the Brazilian context (corruption charges against elected officials and a precarious economic situation) does not seem to have increased the predisposition of the youth to get involved in politics, regardless of the use of Internet. Their participation continues to occur in the attitudinal dimension and not in the behavioral one.

This raises a question about the significance of the Internet in the so called revolution of communications that could alter the level of polarization of the youth and their predispositions to become more active and protagonist in politics. Putnam [36] gives some hints as to why this is occurring based on a qualitative survey in the US. He concludes that "although online participation has been growing rapidly, the digital divide on political uses of the Internet is very great and shows no sign of diminishing" [36].

Thus, as in the past, we must exercise caution in generalizing to the positive effects of new communication technologies as being a panacea for the strengthening of democratic values and catalyst of political engagement of the youth. Our data provide some evidence that the effects have to be analyzed in light of other factors such as the degree of economic and political inequality among the youth and how this affects the way they use the Internet.

In synthesis, I believe the article contributes to further understand how the youth, despite the advances in communications and information technologies continues to evidence attitudes and behavior of a passive and hostile political culture. A second contribution refers to the need of conducting qualitative research with the young, especially in developing countries such as Brazil in order to capture attitudinal and behavioral dimensions not always visible in quantitative analysis. 
The obvious limitation is the fact that I am analyzing only one of the 27 states in Brazil, therefore, generalizations must be viewed with caution.

\section{References}

[1] Young, R. (1956) Approaches to the Study of Politics. Evanston, Illinois.

[2] Nazzari, R.K. (1995) Political Socialization and Citizenship Construction in Parana 1993-1994. Dissertação (Mestrado em Ciência Política), Programa de Pós-Graduação em Ciência Política, Universidade Federal do Rio Grande do Sul, Porto Alegre.

[3] Muxel, A. (1997) The Youth in the 90's: Seeking for a Politics without "Labels". Revista Brasileira de Educação, 5-6, 134-156.

[4] Baquero, M. and Cunha, P. (2010) Corruption as a Limit to the Youth's Political Participation. In: Baquero, R. and Nazzari, K., Eds., Formas de (Ex) presão Juvenil e (IN) visibilidade social, Cascavel-Parana, Editora Coluna do Saber, 55-78.

[5] Sartori, G. (1992) Democracia. In: Sartori, G., Ed., Elementos de Teoría Política, Alianza Universidad, Madrid, 27-62.

[6] Young, I. (2000) Inclusion and Democracy. Oxford University Press, Oxford.

[7] Klicksberg, B. and Rivera, M. (2007) Mobilized Social Capital against Poverty: The Experience of Special Community's Project in Puerto Rico. CLACSO, Buenos Aires.

[8] Touraine, A. (1999) Interview in a Newspaper. El nuevo Siglo, Bogotá, January.

[9] Bourdieu (1984) Questions of Sociology. Minuit, Paris.

[10] Baquero, M. (1997) The Role of Adolescents in the Democratic Construction of Brazil: A Preliminary Study of Political Socialization. Cadernos de Ciência Política, Porto Alegre, 8, 3-34.

[11] CESO Electoral Research Conducted at Every Presidential Election with a Brazilian National Sample. Campinas. São Paulo.

[12] Fundação Telefônica Vivo (2008) The Interactive Generation in IBERO America: Childs and Adolescents in the Screens.

http://generacionesinteractivas.org/upload//libros/A\%20Gerac\%C3\%A3o\%20Intera \%20tiva\%20Na\%20Ibero-Am\%C3\%A9rica\%20.pdf

[13] Miguel, L.F. (2008) The Media and the Decline of Trust in Politics. Sociologias, Porto Alegre, 10, 250-273.

[14] Mesquita, N. (2010) National News Program, Democracy and Trust in Democratic Institutions. In: Moisés, J., Ed., Democracia e confiança. Por que os cidadãos desconfiam das instituições públicas? EDUS, São Paulo.

[15] Viana, F.J.O. (1974) Organization Problems and Decision Problems. The People and the Government. Record Cultural, Rio de Janeiro.

[16] Uricoechea, F. (1978) The Imperial Minotaur. Difel, São Paulo.

[17] Holanda, S.B. (1992) Vision of Paradise. Brasiliense, Rio de Janeiro.

[18] Damatta, R. (1993) About the Nature of Representation in Brazil: Thoughts, Fantasies and Ramblings. In: Damatta, R., Ed., Conta de mentiroso: Sete ensaios de antropologia brasileira, Roccom, Rio de Janeiro, 32-47.

[19] Moises, J.Á. (2008) Political Culture, Institutions and Democratic Lessons of Brazilian Experience. Revista Brasileira de Ciências Sociais, São Paulo, 23, 66.

http://www.scielo.br/scielo.php?pid=S0102-69092008000100002\&script=sci_arttext

[20] Novaes, R. (2005) Youth, Perceptions and Behaviors: Does Religion Make a Differ- 
ence? In: Abramo, H.W., Ed., Retratos da juventude brasileira: Análises de uma pesquisa nacional, Fundação Perseu Abramo, São Paulo.

[21] Gauthier, C. (2001) Training Cultural Educators. Vie Pédagogique, Québec, 118, 23-25.

[22] Baquero, R. (2008) Socioeducation and the School: Challenges to Youth and Adults' Education. Revista Educação Cidadã, 1, 1-15.

[23] Lucas, J.I. (2003) Youth and Anti-Politics in Brazil: A Study of Political Culture and Ideology. Tese (Doutorado em Ciência Política) Programa de Pós-Graduação em Ciência Política, Universidade Federal do Rio Grande do Sul, Porto Alegre.

[24] Cunha (2005) The World's Bank Participation in Citizenship Formation of the Youth of Ceara. 157f. Dissertação (Mestrado em Ciência Política) Programa de Pós-Graduação em Ciência Política, Universidade Federal do Rio Grande do Sul, Porto Alegre.

[25] Silveira, A.F. (2005) Social Capital and Education: Perspectives about Empowerment of the Youth in Porto Alegre. Dissertação (Mestrado em Ciência Política) Programa de Pós-Graduação em Ciência Política, Universidade Federal do Rio Grande do Sul, Porto Alegre.

[26] Araújo, U.F. (2007) The Construction of Democratic Schools: Stories about Complexity, Changes and Resistances. Moderna, São Paulo.

[27] Von Randow, R. (2009) Youth, Participation and Political Culture: A Debate about Which Democratic (Re)construction? In: Colóquio Internacional de Psicossociologia e Sociologia Clínica, 13, Belo Horizonte.

[28] Baquero, M. (2004) An Alternative Road in the Empowerment of the Youth: Social Capital and Political Culture in Brazil. In: Baquero, M., Ed., Democracia, juventude e capital social no Brasil, Editora da UFRGS, Porto Alegre, 120-146.

[29] Nazzari, R.K. (2003) Social Capital, Culture and Political Socialization: The Brazilian Youth. Tese (Doutorado em Ciência Política) Programa de Pós-Graduação em Ciência Política, Universidade Federal do Rio Grande do Sul, Porto Alegre.

[30] Easton, D. (1965) A Framework for Political Analysis. Prentice Hall, Englewood.

[31] Farina, M.B. (2005) The Role of School in the Brazilian Democratic Process: A Case Study of Political Culture and the Dimensions of Civism and Citizenship among the New Generations. Dissertação (Mestrado em Sociologia Política) Programa de Pós-Graduação em Sociologia Política, Universidade Federal de Santa Catarina, Centro de Filosofia e Ciências Humanas.

[32] Soares, L. (2002) Youth and Adult Education: National Curriculum Guidelines. DP $\&$ A, Rio de Janeiro.

[33] Klein, N. (2006) Without Labels. The Tyranny of Brands in a Sold Planet. Record, Rio de Janeiro.

[34] Chang, H. (2007) Kicking Away the Ladder: Development Strategy in Historical Perspective. Anthem, London.

[35] Schmidt, S. (2001) Education in Times of Globalization. DP\&A, Rio de Janeiro.

[36] Putnam, R. (2015) Our Kids. The American Dream in Crisis. Simon \& Schuster, New York.

[37] Castells, M. (1999) The Network Society. Paz e Terra, São Paulo.

[38] Snow, D. and Benford, R. (1992) Master Frames and Cycles of Protest. In: Morris, A. and Mueller, C.M., Eds., Frontiers in Social Movement Theory, Yale University Press, New Haven. 
[39] Diani, M. and Mcadam, D. (2003) Social Movements and Networks: Relational Approaches to Collective Action. Oxford University Press, Oxford. https://doi.org/10.1093/0199251789.001.0001

[40] Easley, D. and Kleinberg, J. (2010) Networks, Crowds and Markets: Reasoning about a Highly Connected World. Cambridge University Press, Cambridge. https://doi.org/10.1017/CBO9780511761942

[41] Bhuiyan, S.I. (2011) Social Media and Its Effectiveness in the Political Reform Movement in Egypt. Middle East Media Educator, 1, 14-20.

[42] Bode, N. and Makarychev, A. (2013) The New Social Media in Russia: Political Blogging by the Government and the Opposition. Problems of Post-Communism, 60, 53-62. https://doi.org/10.2753/PPC1075-8216600205

[43] Bennett, W.L. and Segerberg, A. (2011) Digital Media and the Personalization of Collective Action: Social Technology and the Organization of Protests against the Global Economic Crisis. Information, Communication \& Society, 14, 770-799. https://doi.org/10.1080/1369118X.2011.579141

[44] Gomes, W. (2005) Internet and Participation in Democratic Societies. Revista Famecos, Porto Alegre, 27, 58-78.

[45] Silva, S. (2005) Degrees of Democratic Participation in the Use of Internet by the Capitals' Governments in Brazil. Opinião Pública, Campinas, 2, 450-468. https://doi.org/10.1590/S0104-62762005000200007

[46] LÉVY (1999) Cibercultura. Editora, São Paulo, 34.

[47] Maia, R. (2008) Civic Networks and Internet: Democratic Effects of Associativity. Revista Aurora, No. 2.

[48] Egler, T. (2010) Tecnosocial Networks and Public Policies Democratization. Sociologias, Porto Alegre, 12, 208-236.

[49] Penteado, C.L.C., Santos, M.B.P. and Araujo, R.A. (2010) A Comparative Study between the Sites of the Ministry of Culture of Brazil and Argentina. Cultura (Brasil e Argentina). Revista Teoria \& Sociedade, Minas Gerais, 18, 2.

[50] Eisenberg, J. (2006) Popular Internet and Democracy in the Cities. http://www.egov.ufsc.br/portal/sites/default/files/anexos/30777-32946-1-PB.pdf

[51] Maia, R. and Castro, M.C.S. (2006) Media, Public Sphere and Collective Identities. Editora UFMG, Belo Horizonte.

[52] Mitra, A. (2004) Voices of the Marginalized on the Internet: Examples from a Website for Women of South Asia. Journal of Communication, 54, 492-510. https://doi.org/10.1111/j.1460-2466.2004.tb02641.x

[53] Acklanda, R. and O'neila, M. (2011) Online Collective Identity: The Case of the Environmental Movement. Social Networks, 33, 177-190.

http://www.sciencedirect.com/science/article/pii/S0378873311000153 https://doi.org/10.1016/j.socnet.2011.03.001

[54] Lamb, R. and Poster, M. (2003) Transitioning toward an Internet Culture: An Inter-Organizational Analysis of Identity Construction from Online Services to Intranets. In: Wynn, E., Whitley, E., Myers, M. and Degross, J., Eds., Global and Organizational Discourse about Information Technology, Kluwer Academic Publishers, Norwell.

[55] Soon, C. and Kluver, R. (2014) Uniting Political Bloggers in Diversity: Collective Identity and Web Activism. Journal of Computer-Mediated Communication, 19, 500-515. http://onlinelibrary.wiley.com/doi/10.1111/jcc4.12079/pdf https://doi.org/10.1111/jcc4.12079 
[56] Freire Filho, J.A. (2013) Fans Passional Communication: Expressions of Love and Hate in Social Networks. In: Barbosa, M. and Morais, O., Ed., Comunicação em tempo de redes sociais. Afetos, emoções, subjetividades, INTERCOM, São Paulo, 127-154.

[57] Recuero, R. (2009) Redes Sociais na Internet. Editora Sulina, Porto Alegre.

[58] Primo, A. (2003) The Communication and Long Distance Education according to a Sistemic-Relational Perspective. 292f. Tese (Doutorado em Informática na Educação) Programa de Pós-Graduação em Informática na Educação, Universidade Federal do Rio Grande do Sul, Porto Alegre.

[59] Rheingold, H. (1995) La Comunidad Virtual. Una Sociedade sin Fronteras. Gedisa Editorial, Barcelona.

[60] Almond, G. and Verba, S. (1989) The Civic Culture Revisited. Sage Publications.

Submit or recommend next manuscript to OALib Journal and we will provide best service for you:

- Publication frequency: Monthly

- 9 subject areas of science, technology and medicine

- Fair and rigorous peer-review system

- Fast publication process

- Article promotion in various social networking sites (LinkedIn, Facebook, Twitter, etc.)

- Maximum dissemination of your research work

Submit Your Paper Online: Click Here to Submit

Or Contact service@oalib.com 